CASE REPORT

\title{
Transient Unilateral Lower Limb Palsy after Open Surgery Thoraco-Abdominal Aorta Repair
}

\section{Francesco Corazzi ${ }^{1}$, Stefania Brusa ${ }^{1}$, Enrico Giustiniano ${ }^{1 *}$, Efrem Civilini ${ }^{2}$, Giorgio Luca Poletto ${ }^{2}$ and Ferdinando Raimondi ${ }^{1}$}

${ }^{1}$ Department of Anesthesia and Intensive Care Unit, Humanitas Research Hospital, Italy

${ }^{2}$ Vascular Surgery Unit 1, Humanitas Research Hospital, Italy

*Corresponding author: Enrico Giustiniano, Department of Anesthesia and Intensive Care, Humanitas Research Hospital, via Manzoni 56, 20089 Rozzano, Milan, Italy, Tel: +39-02-8224-7459, Fax: +39-02-8224-4190, E-mail: enrico.giustiniano@ humanitas.it

\begin{abstract}
Paraplegia is one of the most devastating complication after Thoraco-abdominal Aorta (TAA) repair both in open surgery and in endovascular procedure, caused by critical obstruction to blood perfusion of the Spinal Cord.

Spinal Cord Ischemia ( $\mathrm{SCl}$ ) may be due to hemodynamic impairment and/or to segmental artery occlusion during aortic clamping $[1,2]$.

We report a case of chronically dissected Thoraco-abdominal Aortic Aneurysm (TAAA) which showed unilateral transient neurological impairment of the left lower limb, postoperatively.
\end{abstract}

\section{Keywords}

Spinal cord injury, Aorta, Surgery

\section{Case Report}

A 78ys old male (ASA 3, BMI $26 \mathrm{~kg} / \mathrm{m}^{2}$ ) was submitted to open surgical TAA repair due to dissection of aneurism (Crawford 2 - Stanford B) [3,4].

Aorta was replaced by a prosthesis from the isthmus to iliac carrefour with re-implantation of celiac trunk, superior mesenteric artery and renal arteries. Two couple of intercostal and lumbar arteries were re-implanted to the prosthesis.

Anamnesis included cholecystectomy, hypertension and coronary artery by-pass graft (CABG) due to acute myocardial infarction (AMI), dislipidemia, G6PD deficit, allergy to milk proteins, liver steatosis and severe chronic obstructive pulmonary disease (COPD) with FEV1/FVC ratio 0.43 and FEV1 $1.12 \mathrm{~L}$ (44\%).

The pre-operative echocardiogram showed: Mild hypertrophy of left ventricle walls (13-14 mm), left ventricle end-diastolic volume at upper limit (LVEDVi $=74 \mathrm{ml} /$ $\left.\mathrm{m}^{2}\right)$, inferior wall and interventricular septum were akinetic providing a reduced ejection fraction (LVEF 0.38) that did ameliorate at dobutamine echo-stress (LVEF 0.47); furthermore it showed mild aortic valve stenosis (medium pressure gradient $20 \mathrm{mmHg}$ with valve area $\left.1.2 \mathrm{~cm}^{2}\right)$.

He underwent general anesthesia that was inducted by Midazolam $5 \mathrm{mg}$ iv, Fentanyl $200 \mathrm{mcg}$ iv. After myorelaxation with cis-Atracurium $12 \mathrm{mg}$ iv a double-lumen endotracheal tube $\mathrm{n} .41$ was inserted to connect the patient's airways to mechanical ventilator (Vt 560; respiratory rate 12; positive end-expiratory pressure 5 $\left.\mathrm{cm} \mathrm{H}_{2} \mathrm{O}\right)$; he received a gas mixture of oxygen/air $\left(\mathrm{FiO}_{2}\right.$ 40-60\%) and Sevoflurane 1-2\%, as appropriate. Myorelaxation continued with cis-Atracurium $1 \mathrm{mg} / \mathrm{kg} / \mathrm{h}$. Remifentanil 0.1-0.2 mcg/ $\mathrm{kg} / \mathrm{min}$ was administered.

During unilateral lung ventilation Vt was $420 \mathrm{ml}$ and respiratory rate was adjusted according blood gas analysis (BGA).

Intraoperative monitoring included ECG (II and V), non-invasive blood pressure (NIBP), peripheral saturimetry $\left(\mathrm{SpO}_{2}\right)$ and end-tidal carbon dioxide $\left(\mathrm{EtCO}_{2}\right)$. After 
patient fell asleep a subarachnoid catheter (CODMAN ${ }^{\circledR}$ Johnson \& Johnson $14 \mathrm{G} 40 \mathrm{~cm}$ ) was inserted at L3-L4 level to monitor cerebro-spinal fluid pressure $\left(\mathrm{P}_{\text {csf }}\right)$ and lactate concentration ( $\left.\mathrm{Lac}_{\mathrm{css}}\right)$ and to drain the fluid aiming to assure $P_{\text {csf }} \leq 10 \mathrm{mmHg}$.

We assured a double arterial line to monitor blood pressure invasively (ABP): Right radial artery (RRA) and right femoral artery (RFA). It permitted to monitor $A B P$ due to heart function (RRA) and to left atrium-left femoral artery by-pass (LALFBP) bio-pump (Bio-Console ${ }^{\circledR}$ 560 - Medtronic, Inc., Minneapolis, MN, USA) during the clamping phase of the operation: Target values were systolic pressure $140-150 \mathrm{mmHg}$ and blood pressure 60-70 $\mathrm{mmHg}$, respectively.

Cardiac Index and Stroke Volume Variation were measured by the FloTrac/Vigileo ${ }^{\mathrm{TM}}$ (Edwards Life science, Irvine, CA, US).

During the operation, patient received trans-esophageal echocardiography (TEE) evaluation of cardiac function.

Unfractionated heparin (UFH) 5000 UI was administered 3 minutes before aortic clamping.

During supraceliac aortic clamping (98 minutes) the bio-pump assured blood delivery to splanchnic district by the right femoral artery cannulation. Renal Arteries were cannulated and kidneys perfused by cold $\left(5^{\circ} \mathrm{C}\right)$ Custodiol ${ }^{\circledR}$ HTK solution (Pvt) Ltd until renal circulation restored $(300 \mathrm{ml}$ bolus followed by $10 \mathrm{ml} / \mathrm{min}$ for 85 minutes).

After anesthesia induction hemodynamic impair- ment occurred and Dobutamine $2-5 \mathrm{mcg} / \mathrm{kg} / \mathrm{min}$ needed to restore a safe cardiocirculatory setting. It was stopped after 30 minutes as cardiocirculatory assessment was satisfactory.

Five minutes after UFH administration, Activated Clotting Time (ACT) resulted 227 seconds. Then Aorta was clamped and bio-pump support started. It's blood flow ranged $1600-2100 \mathrm{ml} / \mathrm{min}$ according hemodynamics and blood loss. It provided a perfusional blood pressure of $60-85 \mathrm{mmHg}$. RRA mean blood pressure was $70-$ $90 \mathrm{mmHg}$.

Total bleeding was $6200 \mathrm{ml}$ out of which $2350 \mathrm{ml}$ were collected in two red cell savers (SORIN Group Deutschland, Munich, Germany) and administered to the patient. Furthermore, 8 units $(2300 \mathrm{ml})$ of concentrated red blood cells (RBC), 7 units $(1793 \mathrm{ml})$ of fresh frozen plasma (FFP) and 1 unit of pool-Platelets were transfused. Total crystalloid and colloid (Uman Albumin $20 \%$ ) solutions resulted $3100 \mathrm{ml}$ and $300 \mathrm{ml}$, respectively.

FloTrac/Vigileo ${ }^{\mathrm{TM}}$ and TEE during operation guided the administration of fluids and vasoactive drugs. During the clamping phase Norepinephrine (NE) 0.03$0.05 \mathrm{mcg} / \mathrm{kg} / \mathrm{min}$ needed to assure the hemodynamics goals.

Target Cerebro-Spinal Fluid pressure $\left(\mathrm{P}_{\text {csf }}\right)$ was $\leq 10$ $\mathrm{mmHg}$ and when it was greater $10 \mathrm{ml}$ of CSF were withdrawned. It resulted always sufficient to restore the target $P_{\text {csf }}$.

Table 1 reports the main intraoperative data.

Table 1: Intraoperative data.

\begin{tabular}{|c|c|c|c|c|c|}
\hline & $\begin{array}{l}\text { After } \\
\text { induction }\end{array}$ & Aortic clamping & LALFBP pump off & $\begin{array}{l}\text { Aortic } \\
\text { unclamping }\end{array}$ & Operation end \\
\hline RRA MAP (mmHg) & 80 & 90 & 70 & 50 & 60 \\
\hline RFA MAP (mmHg) & 75 & 85 & 60 & 43 & 50 \\
\hline $\mathrm{pH}$ & 7.40 & 7.20 & 7.32 & 7.36 & 7.34 \\
\hline P/F ratio & 707 & 351 & 406 & 253 & 268 \\
\hline $\mathrm{pCO}_{2}(\mathrm{mmHg})$ & 42 & 47 & 44 & 43 & 44 \\
\hline Lactatemia $(\mathrm{mmol} / \mathrm{L})$ & 0.6 & 0.6 & 4 & 4.4 & 4.5 \\
\hline $\mathrm{BE}(\mathrm{mmol} / \mathrm{L})$ & 1.0 & -8.9 & -3.2 & -1.1 & -2 \\
\hline $\mathrm{Hb}(\mathrm{g} / \mathrm{dL})$ & 11.8 & 6.8 & 8.1 & 6.5 & 7.8 \\
\hline $\mathrm{Lac}_{\mathrm{csf}}(\mathrm{mmol} / \mathrm{L})$ & 0.8 & 1.6 & - & 1.8 & 2.2 \\
\hline $\mathrm{P}_{\mathrm{csf}}(\mathrm{mmHg})$ & 12 & 9 & 12 & 13 & 8 \\
\hline CSF drainage (ml) & 40 & 20 & 10 & 10 & - \\
\hline $\mathrm{Cl}\left(\mathrm{L} / \mathrm{min} / \mathrm{m}^{2}\right)$ & 2 & 2.3 & 2.5 & 3.2 & 3 \\
\hline $\operatorname{SVV}(\%)$ & 5 & 11 & 22 & 10 & 12 \\
\hline Blood loss (ml) & - & 500 & 1100 & 2000 & 6200 \\
\hline Cristalloids (ml) & 500 & 1500 & 2000 & 2500 & 3100 \\
\hline Colloids (ml) & - & 100 & 100 & 100 & 300 \\
\hline Red Blood Cells (unit) & - & - & 4 & 7 & 8 \\
\hline Fresh Frozen Plasma (unit) & - & - & 2 & 5 & 7 \\
\hline Pool-PLTs (unit) & - & - & - & 1 & - \\
\hline Diuresis $(\mathrm{ml})$ & - & - & - & 120 & 250 \\
\hline
\end{tabular}

RRA MAP: Right Radial Artery Mean Arterial Pressure; RFA MAP: Right Femoral Artery Mean Arterial Pressure; $\mathrm{P} / \mathrm{F}$ ratio: $\mathrm{pO}_{2} /$ $\mathrm{FiO}_{2}$; BE: Base Excess; $\mathrm{Hb}$ : Hemoglobin; Lac $_{\text {csf }}$ : Lactate concentration in cerebro-spinal fluid; $P_{\text {csf }}$ : Cerebro-spinal Fluid Pressure; CSF: Cerebro-Spinal Fluid. 
Table 2: Postoperative data.

\begin{tabular}{|c|c|c|c|c|c|c|}
\hline Postoperative hours & 0 & $6^{*}$ & $16^{* *}$ & 24 & 48 & 72 \\
\hline $\mathrm{pH}$ & 7.11 & 7.15 & 7.49 & 7.51 & 7.56 & 7.40 \\
\hline Lactatemia (mmol/L) & 9.6 & 11.2 & 4.2 & 1.3 & 1.0 & 1.0 \\
\hline $\mathrm{Lac}_{\mathrm{csf}}(\mathrm{mmol} / \mathrm{L})$ & 4.6 & 6.9 & 4.6 & 1.7 & 1.6 & 1.7 \\
\hline$P_{\text {csf }}(\mathrm{mmHg})$ & 16 & 18 & 15 & 18 & 14 & 15 \\
\hline $\mathrm{PP}_{\mathrm{csf}}(\mathrm{mmHg})$ & 44 & 45 & 68 & 72 & 79 & 78 \\
\hline $\mathrm{NE}(\mathrm{mcg} / \mathrm{kg} / \mathrm{min})$ & 0.09 & 0.10 & 0.15 & 0.05 & - & - \\
\hline Ep (mcg/kg/min) & 0.15 & 0.15 & 0.05 & - & - & - \\
\hline CSF Drainage (ml) & - & 20 & 10 & $5^{\# \#}$ & $5^{\# \#}$ & $5^{\# \#}$ \\
\hline $\mathrm{Cl}\left(\mathrm{L} / \mathrm{min} / \mathrm{m}^{2}\right)$ & 3.2 & 3.3 & 3.4 & 4.1 & 2.8 & 3.3 \\
\hline SVV (\%) & 15 & 18 & 10 & 8 & 7 & 8 \\
\hline MAP $(\mathrm{mmHg})$ & 60 & 63 & 83 & 90 & 93 & 95 \\
\hline $\mathrm{HR}(\mathrm{bpm})$ & 72 & 110 & 90 & 82 & 55 & 55 \\
\hline Diuresis $(\mathrm{ml} / \mathrm{h})$ & 40 & 32 & 60 & 80 & 100 & 100 \\
\hline $\mathrm{Hb}(\mathrm{g} / \mathrm{dL})$ & 9.4 & 7.7 & 11.5 & 11.5 & 11.3 & 10.2 \\
\hline Platelets count $\left(/ \mathrm{mm}^{3}\right)$ & 51000 & 92000 & 72000 & 71000 & 62000 & 47000 \\
\hline Serum Fibrinogen (mg/dL) & 71 & 133 & 213 & 202 & 233 & 365 \\
\hline Bleeding $(\mathrm{ml} / \mathrm{h})$ & 300 & 150 & 10 & - & - & - \\
\hline Inferior limbs motility & $\begin{array}{l}\text { not } \\
\text { evaluable }\end{array}$ & $\begin{array}{l}\text { Left } \operatorname{limb}_{\text {deficit }} \\
\text { dit }\end{array}$ & $\begin{array}{l}\text { Left limb } \\
\text { deficit }\end{array}$ & $\begin{array}{l}\text { Recovered } \\
\text { motility }\end{array}$ & $\begin{array}{l}\text { Recovered } \\
\text { motility }\end{array}$ & $\begin{array}{l}\text { Recovered } \\
\text { motility }\end{array}$ \\
\hline
\end{tabular}

"Patient re-entered operative room for surgical hemostasis; " ${ }^{\#}$ After sedation stopped for $1 \mathrm{~h}$; ${ }^{\# T o}$ measure $\mathrm{Lac}_{\mathrm{csf}}$; Lac $_{\mathrm{csf}}$ : Lactate concentration in cerebrospinal fluid; $\mathrm{P}_{\text {csf }}$ : Cerebro-spinal Fluid Pressure; CI: Cardiac Index; SVV: Stroke Volume variation; MAP: Mean Arterial Pressure; HR: Heart Rate; Hb: Hemoglobin.

Postoperative analgesia was performed by a double supra-fascial multi-holed catheter $22.5 \mathrm{~cm}$ 19-gauge (Painfusor Catheter ${ }^{\odot} 2017$ Plan 1 Health, Amaro-Udine, Italy) through which Ropivacaine $0.4 \%$ was administered at a rate of $10 \mathrm{ml} / \mathrm{h}$.

At the end of the operation, patient continued sedation by Propofol $2 \% 10 \mathrm{ml} / \mathrm{h}$ and Remifentanil 0.05 $\mathrm{mcg} / \mathrm{kg} / \mathrm{min}$. The two-lumen endotracheal tube was substituted by a single lumen oro-tracheal tube n. 8 and patient was admitted to our ICU for postoperative surveillance and mechanical ventilation support. Table 2 shows the post-operative data.

At the ICU admission, BGA showed compensated lactic acidosis and a significant bleeding that continued for 6 hs. A first "sedation window" (1 h stopped Propofol and Remifentanil) showed a motor deficit of the left lower limb.

Blood loss was thought to be due to coagulation system impairment because serum Fibrinogen was $71 \mathrm{mg} /$ $\mathrm{dL}$ and Platelet counts lowered to $51000 / \mathrm{mm}^{3}$, International Normalized Ratio (INR) was 1.79. Since surgeons did not indicate operative revision, medical treatment was chosen.

After Fibrinogen administration 3 g i.v. serum concentration reached $133 \mathrm{mg} / \mathrm{dL}$. Furthermore 10 units of RBC, 5 units of FFP and 1 unit of pool-PLTs were administered to maintain a sufficient serum $\mathrm{Hb}$ and aiming to recover the coagulation system alteration. Hemodynamics needed to be supported by Norepinephrine 0.09 $\mathrm{mcg} / \mathrm{kg} / \mathrm{min}$ and Epinephrine $0.15 \mathrm{mcg} / \mathrm{kg} / \mathrm{min}$ (after cardiac ultrasounds examination).

Since therapy resulted unsuccessful, patient re-entered the operative room for surgical hemostasis that was decisive. After the re-operation he returned to ICU. A second longer "sedation window" confirmed the left lower limb paresis. Sensitive function was not adequately evaluable as the patient showed psycho-motor agitation (upper limbs and right lower limb) and was not collaborative. $\mathrm{P}_{\text {csf }}$ was $<10 \mathrm{mmHg}$ and $\mathrm{Lac}_{\text {csf }}$ resulted $4.6 \mathrm{mmol} / \mathrm{L}$. Mean arterial pressure (MAP) was 83 $\mathrm{mmHg}$ and the difference MAP - $\mathrm{P}_{\text {csf }}$ (i.e. the perfusion pressure of spinal cord, $\mathrm{PP}_{\text {csf }}$ ) was $68 \mathrm{mmHg}$. Then we modified the vasoactive drug (NE) administration rate to reach a better perfusion pressure of the spinal cord (> $70 \mathrm{mmHg}$ ).

At 48 post-operative hours $\mathrm{PP}_{\text {csf }}$ was $79 \mathrm{mmHg}$ and $\mathrm{Lac}_{\mathrm{csf}}$ lowered to $1.6 \mathrm{mmo} / \mathrm{L}$. During the preceding 12 hours sedation was completely stopped and we could observe a recovering of the neurological deficit of the left lower limb.

During the following ICU-staying patients experienced a worsening of respiratory function due to pneumonia and atelectasis of the left lower lung lobe, that was treated as appropriate (antibacterial drugs, long-lasting mechanical ventilation even in prone position).

\section{Discussion}

We reported a case of transient unilateral plegia of the left lower limb in a subject who underwent open surgical repair of chronically dissected TAAA.

We consider that the peculiarity of such a case was the one-side neurological deficit subsequent to the operation and its complete recovering.

Post-operative $\mathrm{SCl}$ is a devastating complication following TAA surgery. Literature reports about cases of 
paraplegia after this kind of surgery is plentiful, but a one-side lower palsy lasting only few hours post-operatively has not been published as yet, at our knowledge.

During the operation we monitored intratecal pressure $\left(P_{c s f}\right)$ and the spinal cord perfusion pressure $\left(P P_{c s f}\right)$ along with Lactate concentration into CSF ( Lac $\left._{\text {csf }}\right)$ because it may be a marker of local ischemic suffering [58]. Lac $\mathrm{csf}_{\text {and }} \mathrm{P}_{\mathrm{csf}}$ did not showed significant alterations, intraoperatively. On the contrary, $\mathrm{P}_{\text {csf }}$ lowered just after surgery consequently to hemodynamic impairment due to severe bleeding and Lac $_{\text {csf }}$ increased. Then we may infer that $\mathrm{SCl}$ occurred during hemorrhage despite blood transfusions and vasoactive drugs administration.

After surgical hemostasis, intrathecal pressure recovered, but lactate concentration into cerebrospinal fluid, even lowered, remained above normal values [5].

Unexpectedly, after 72 hours post-operation Lac recovered and lower left limb sensitive-motor function restored.

The unique publication we found about unilateral lower limb paralysis reports a case about abdominal aortic aneurysm repair. It is a rare complication after aorto-iliac surgery: The diagnosis was ischemic lumbar plexopathy (Magnetic Resonance Imaging of the spine was negative 3 weeks later). The patient showed a partial deficit when discharged [9].

Nowadays we know the vascularization of the spine cord better than when the arteria radicularis magna (ARM) was described for the first time [10]. Nevertheless, we are not able to explain all post-surgical spine cord damage due to ischemia with certainty, as yet.

Our case was not investigated by Magnetic Resonance Imaging because of severe respiratory impairment requiring mechanical ventilation and then we considered very dangerous moving the patient to Radiology Department for the exam. Furthermore, the neurologist consultant did not indicate further exams because the patient recovered from unilateral palsy completely.

We are aware it is a great limitation to this case report. But, despite this limitation, we consider it may be worthy of report due to the rarity of the case and also to overcome the anecdotal passing on the knowledge about such an issue.

\section{Conflict of Interest}

Authors declare they have not any conflict of interest and they did not received any fund for such a report.

\section{References}

1. Khoynezhad A, Bello R, Smego DR, Nwakanma L, Pletis KA (2005) Improved outcome after repair of descending and thoracoabdominal aortic aneurysms using modern adjuncts. Interact Cardiovasc Thorac Surg 4: 574-576.

2. Weigang E, Hartert M, Siegenthaler MP, Beckmann NA, Sircar R, et al. (2006) Perioperative management to improve neurologic outcome in thoracic or thoracoabdominal aortic stent-grafting. Ann Thorac Surg 82: 1679-1687.

3. Crawford ES, Crawford JL, Safi HJ, Coselli JS, Hess KR, et al. (1986) Thoracoabdominal aortic aneurysms: preoperative and intraoperative factors determining immediate and long-term results of operations in 605 patients. J Vasc Surg 3: 389-404.

4. Daily PO, Trueblood HW, Stinson EB, Wuerflein RD, Shumway NE (1970) Management of acute aortic dissections. Ann Thorac Surg 10: 237-247.

5. Holbrook I, Beetham R, Cruickshank A, Egner W, Fahie-Wilson $M$, et al. (2007) National audit of cerebrospinal fluid testing. Ann Clin Biochem 44: 443-448.

6. Leen WG, Willemsen MA, Wevers RA, Verbeek MM (2012) Cerebrospinal fluid glucose and lactate: age-specific reference values and implications for clinical practice. PLoS One 7: e42745.

7. Giustiniano E, Malossini SE, Pellegrino F, Cancellieri $F$ (2013) Subarachnoid fluid lactate and paraplegia after descending aorta aneurysmectomy: Two compared case reports. Case Rep Anesthesiol 2013: 925739.

8. Giustiniano E, Ruggieri N (2014) Is intrathecal lactate concentration monitoring helpful for postoperative paraplegia after descending aorta surgery? J Clin Anesth 26: 506-508.

9. Deylgat B, Wallaert P, De Smul G, Van Lysebeth L, Ceuppens $H$ (2009) Unilateral lower limb paralysis after aortobifemoral bypass graft for ruptured abdominal aortic aneurysm: A case report. Vasc Endovascular Surg 43: 606-609.

10. Kieffer E, Richard T, Chiras J, Godet G, Cormier E (1989) Preoperative spinal cord arteriography in aneurysmal disease of the descending thoracic and thoracoabdominal aorta: Preliminary results in 45 patients. Ann Vasc Surg 3: 34-36. 